\title{
Clio
}

Women, Gender, History

37 | 2013

When Medicine Meets Gender

\section{The reconfiguration of gender relations in Syrian- American feminist discourse in the diasporic conditions of the late nineteenth century}

\section{Dominique Cadinot}

Translator. Jeffrey Burkholder

\section{(2) OpenEdition Journals}

\section{Electronic version}

URL: http://journals.openedition.org/cliowgh/413

DOI: $10.4000 /$ cliowgh.413

ISSN: 2554-3822

\section{Publisher}

Belin

\section{Electronic reference}

Dominique Cadinot, «The reconfiguration of gender relations in Syrian-American feminist discourse in the diasporic conditions of the late nineteenth century », Clio [Online], 37 | 2013, Online since 15 April 2014, connection on 01 May 2019. URL : http://journals.openedition.org/cliowgh/413 ; DOI : 10.4000/ cliowgh.413 


\section{The reconfiguration of gender relations and Syrian- American feminist discourse in the transnational space of the latter nineteenth century}

The prejudices concerning Arab-Muslim civilization that have become so ingrained in popular imagination began to be perpetuated in the United States at the end of the Barbary Wars, fought by the Americans against the Ottoman regencies of North Africa between 1801 and 1815. This first US victory over the Arab world was perceived by Americans as a sign from Providence, confirming the superiority of their values and ideals over those of their adversaries. It is from this era that the image of the Arab woman begins to be associated with that of the odalisque of the harem, a sexual object, or with that of the ignorant wife reduced to servitude under her veil. ${ }^{1}$ However, in the United States of the early $20^{\text {th }}$ century, immigrant women from the Middle East took advantage of their exile and their contact with American society to start breaking away from traditional social practices, thus demonstrating their will to free themselves from these gender stereotypes. These women, who came from a mainly Christian social and intellectual élite, were very active within their small immigrant group, developing a feminist discourse which was part of a redefinition of collective identity, and which simultaneously echoed the voices of their female compatriots remaining in the Middle East. ${ }^{2}$

1 On representations of the harem and of Arab women, see Taraud 2011.

2 The methodological variations of counting systems, subject to the will of administrations, have made it hard to compile and compare statistics on the demographics of the early Arab immigrants. Nevertheless, my research shows that this immigration began in the second half of the nineteenth century, only 
Up to 1997, the year that saw the publication of Evelyn Shakir's book Bint Arab: Arab and Arab American Women in the United States, the history of Arab-American women was a blind spot for American scholarly research into the ethnicisation of the Arabic-speaking community in the United States. To be sure, since the tragic attacks of September $11^{\text {th }}, 2001$, we have seen an abundance of work on the stigmatization or the political engagement of members of this community; but French historiography by contrast has remained summary at best - if not totally silent on the role women played in the integration and the visibility of the group in question. ${ }^{3}$ The objective of this article is therefore to propose, drawing on a synthesis of the principal Anglo-American works having examined the subject, some lines of inquiry regarding the conditions in which Arab-American feminism appeared and matured around the turn of the twentieth century. The idea is to study the emancipatory path of "Syrian-American" women and to identify the strategies put into place to take advantage of the different aspects of their diasporic condition. After analyzing the motivations that led Arab women to emigrate toward the United States, I shall turn my attention to the processes of integration and emancipation of these immigrant women, as well as the mechanisms accompanying the awakening of a feminist consciousness. Finally, I shall seek to understand how the transition from a general feminist discourse to a specifically "SyrianAmerican" discourse was made.

\section{The Emigration of "Syrian" Women: Features and Factors}

The history of emigration from the Middle East toward the United States began in the second half of the nineteenth century. Immigration flowed mainly from the region of the Middle East known in Arabic as Bilad al-Shâm, which included the "Syrian"

concerned a few hundred people in 1887 and accelerated rapidly to attain 20,000 people in 1898 (Cadinot 2006: 92-93).

3 To my knowledge, there has been no Francophone research done on the question of Arab feminism in the United States. The Arab-American group has however been the subject of a few scientific publications in the form of monographs or articles. See for example Parrs 2005, or Latrache 2006. 
provinces of the Ottoman Empire, composed of the present-day territories of Lebanon, Israel, western Syria and Palestine. We need to clarify straight away the terminology that will be used to discuss the group in question. Until 1899, American immigration services (e.g., The US Census Bureau, Immigration and Naturalization Services) used the expression "Eastern Turks" to distinguish Arabic-speaking peoples from Ottoman-Turkish populations. After 1900, these services adopted the term "Syrian" to designate all newcomers from the Middle East. This term, which was taken up by the members of the Arabic-speaking immigrant community, will therefore be used to refer to immigrants of Arabic culture who came to the United States prior to 1918, the date that marks the final stage of Ottoman Empire's dismemberment. To refer to members of the second or third generation of this community, I shall use the term "SyrianAmerican."

The first researchers interested in this immigration often described it as an exclusively masculine phenomenon. ${ }^{4}$ The more recent research of Evelyn Shakir, however, has established that "Syrian" women represented between 1901 and 1910 more than 31\% of Arab immigrants, while during the same period Italian women made up only $22 \%$ and Greek women barely $5 \%$ of their immigrant communities. ${ }^{5}$ It has moreover been demonstrated that, in contradiction to the usual image of the submissive and dependent Eastern woman, it wasn't rare for immigrant women to be unaccompanied (that is to say, not under the guardianship of a husband or other male family member). The case of Camilla Gibran mother of the future Syrian-American writer Khalil Gibran - who came to the United States with her children but without her husband, is a well-known example of an unaccompanied woman. ${ }^{6}$ How should one explain the very significant presence of women within this immigration group from the Middle East?

4 See Hitti 1924 or Younis 1995

5 Shakir 1997: 202.

6 On the social integration of "unaccompanied" female European immigrants, see Gabbacia 1995. 
The political context of the Ottoman provinces constitutes one explanation. The recurrence of religious conflicts that pitted Christians against Muslims, aggravated by Western powers, was certainly a powerful reason to emigrate. The 1860 civil war in Mount Lebanon between the Maronites and the Druze, responsible for several thousand deaths, has indeed been often cited as one of the main causes of this emigration. ${ }^{7}$ Even if numerous legends circulated in the East about American cities whose streets were paved with gold, the primary motivation was not only to make one's fortune in America, but to escape with one's family from religious persecution and subjugation by Ottoman power.

However, all specialists agree that the most powerful driving force was the role played by American Protestant missionaries who, as early as 1820 , landed in the city of Beirut. ${ }^{8}$ Inspired by the millenarian tradition, these Presbyterian missionaries considered the conversion of heretics and "infidels" as the prerequisite to Christ's future reign on Earth. Upon arriving, they noticed that European missionaries benefited from a considerable head start. To distinguish themselves from their French and English competitors, the Americans made two important decisions. They undertook a new Arabic translation of the Bible and, secondly, they sought to spread their evangelist proselytism to Christian women: "The mothers of Syria will exert our influence in the homes of backward nations." "That the Christian women of the East should become the Protestant apostolate - such was the goal of American missionaries. They began offering young Arab women the opportunity to enter the classroom. In order to do so, they organized and financed the construction of schools first in Beirut and then in the surrounding villages. In 1835, the wife of the Reverend Smith founded the American School for Girls in Beirut, the first girls' school in the Ottoman Empire. ${ }^{10}$ In the following years, more than thirty

7 See Naff 1981: 110 or Younis 1995: 47.

8 See Younis 1995: 52; McIrvin Abu-Laban 1989: 49.

9 Quoted in Younis 1995: 64.

${ }^{10}$ The participation of missionaries' wives was encouraged by the regulatory authorities, as is testified by a declaration made by one of heads of the American Board of Commissioners for Foreign Missions: "A lady with a missionary spirit can be quite as useful as her husband - often more so", quoted in Clinton 1999: 44. 
schools (for girls or coeducational) opened their doors. In 1866, a new milestone was reached with the foundation of the first coeducational university: the Syrian Protestant College, renamed the American University of Beirut (AUB) in 1920. Young "Syrian" women could, in this institution, receive education to be teachers, engineers or nurses. Although the young women graduating were at first mostly Christian, the reputation of the American college quickly encouraged the Druze community to send its share of female students as well.

One of the effects of American missionary zeal was thus to give rise - by means of education and the possibility of the upward social mobility that this education seemed to promise -to a passion for the New World. This is Evelyn Shakir's conclusion:

Through their textbooks and curriculum American missionaries helped plant the U.S. in the imagination of thousands of people throughout Syria. ${ }^{11}$

So American missions appear to have promoted an American social model among "Syrian" women, helping them to attain greater gender equality in particular. This promotion of a more egalitarian society unintentionally provoked a process of emigration.

But did this new Promised Land keep its promises? ${ }^{12}$ In what context did these "Syrian" women coming from the Eastern coasts of the Mediterranean integrate into the United States, and what possibilities of emancipation were offered to them there?

From economic integration to political struggle

Even though, at the end of the nineteenth century, there was already a neighborhood called Little Syria around Washington Street of New York City, it was on the road that the greatest number of "Syrians" could be found. Pack peddling was most common trade adopted by Arab immigrants. Comprising religious objects (known as Jerusalem products) at first, and soon after that clothing, jewelry and hardware,

\footnotetext{
11 Quoted in Shakir 1997: 23.

${ }^{12}$ The expression "Promised Land" is used by the reverend Henry Jessup when he regretfully takes note of the massive emigration of his students toward the United States: "The Promised Land is no longer each side of the Jordan River, but each side of the Mississippi”, quoted in Younis 1995: 125.
} 
their merchandise was easily transportable from Manhattan Island to the surrounding countryside. Thanks to travelling sales, a commercial network developed that ensured the financial independence of newcomers to the trade. Distribution centers were soon created, first in the largest New England cities and then across the entire East coast. The women of the community participated greatly in this activity; nearly $80 \%$ of them worked as peddlers, often autonomously. ${ }^{13}$ How can one explain this self-emancipation of "Syrian" women from the family sphere, in a foreign country no less? One explanation is that American customers, who often lived in isolation, were for prudence's sake more willing to open the door of their home to women. The nature of the goods being sold might be another explanation. However, one should also bear in mind that the pioneers of immigration from the Middle East came, for the most part, from very modest social classes (farmers, artisans, simple laborers). Consequently, many of them lacked the capital necessary to set up their own business. But more importantly, peddling was a particularly lucrative activity. According to Alixa Naff, peddling could generate an annual income of $\$ 1,000$ while the manufacturing sector only brought in $\$ 600$ on average. ${ }^{14}$ Recognizing the opportunity for enrichment, the men of the community may have authorized their wives and daughters to exit the domestic sphere and may then have simply gone along with their success.

However, women's participation in this commercial activity as well as the degree of freedom that peddling afforded them gave rise to criticism. Discordant voices were heard in the very heart of the immigrant community. In 1899, for example, one could read in the pages of the New York-based Arabic newspaper $\mathrm{Al}-\mathrm{Huda},{ }^{15}$ an article by the "Syrian" journalist Layyat Barakat who, while encouraging her fellow countrywomen to pursue a professional activity, warned against the dangers and disgraceful character of pack peddling:

\footnotetext{
${ }^{13}$ Naff quoted in Gualtieri 2004: 7.

${ }^{14}$ Naff 2002: 7.

15 This weekly Arabic newspaper was created in 1898 in New York and published until 1993.
} 
It is often dangerous for good, simple-hearted girls who [can become]... exposed to evil and whoredom. ${ }^{16}$

The journalist goes on to encourage young women to take jobs rather as housemaids in order to do the tasks traditionally reserved to their sex:

She will learn virtue and housekeeping, becoming fit to manage her own home and children in the right manner. ${ }^{17}$

In the same way, Eastern Catholic authorities in United States sometimes condemned the behavior of immigrant women. The following, for example, is what the priest of the Greek Orthodox Cathedral of Brooklyn declared on the subject:

It is disgraceful the way Syrian women overstep their boundaries on the pretext that they are living under free skies. ${ }^{18}$

The role and the success of women in the pack peddling trade also attracted the attention of certain American journalists who denounced the immorality of female peddlers.

They sometimes take their babies with them, but more often they leave them behind, to be looked after by their idle husbands. It is not the custom in this country to let the women work and have the men remain idle at home. ${ }^{19}$

One thus observes that, in spite of the distance from their homeland, working class "Syrian" women involved in pack peddling were exposed both to the conservatism of more elite Syrian immigrants and to the xenophobic prejudice of American public opinion; to the middle-class Syrians who held onto traditional family values, women peddlers seemed to overstep their natural place; to the Americans, women's peddling appeared as a sign of cultural or even racial inferiority. Source of controversy though it was, peddling nevertheless contributed to a redefinition of gender relations. As

\footnotetext{
${ }^{16}$ Quoted in Shakir 1997: 11.

${ }^{17}$ Quoted in Shakir 1997: 41.

${ }^{18}$ Quoted in Gualtieri 2004: 7.

${ }^{19}$ Quoted in Shakir 1997: 40.
} 
Akram Fouad Khater affirms: "Women's experience as peddlers gave them a greater sense of control."'20

Nevertheless, if this professional niche gave immigrant women opportunities for emancipation, by the early twentieth century peddling was no longer the principal activity of Syrian Americans. Men and women of the first group of immigrants eventually settled down to run inns or small business, having harvested the fruits of their labor, or having been overcome by competition from mail-order businesses. Additionally, the US economy was entering a phase of exceptional growth. New mechanized factories came to replace old workshops and Syrian Americans constituted a cheap source of labor. The Ford River Rouge factory complex in Dearborn Michigan, a symbol of American entrepreneurial energy, hired hundreds of Arab workers during its opening year of 1917. Similarly, in New England, gigantic industrial complexes tapped immigrant populations for their workforce. The textile industry, dating back to the eighteenth century in the state of Rhode Island, began to attract groups of young Lebanese Maronites who settled in Providence, as well as many Greek-Orthodox Christians originally from Damascus or Aleppo. Here as well, women seized the opportunity to support their family economically and to emancipate themselves from the traditional patriarchy. In fact, the need for a female workforce was such that in 1910, in Fall River, Massachusetts, practically all the young unmarried girls of Arabic origin were employed in cotton mills.

Yet, in this period, the American labor movement was affected by a new current that supported the unionization of foreign workers. The leaders of the Industrial Workers of the World considered division between American workers and immigrant workers to be the result of a strategy by employers seeking to weaken the strength of unions. The activism of the labor movement thus incited Arab workers to get involved in the power struggle between the industrialists and the working class. In 1912, during the famous strike in the textile factories of the American Woolen Company in Lawrence, Massachusetts, Arab women joined their fellow workers, who were mostly of Italian origin, in demanding wage increases and the

${ }^{20}$ Khater 2001: 121. 
abolition of discrimination between Americans and immigrants. Syrian Americans were all the more involved since it was the execution of the young John Rami, an immigrant from Beirut, that sparked the events. ${ }^{21}$ For over ten weeks, thousands of Arab women organized picket lines, raised funds for solidarity and confronted police forces with banners bearing the slogan "We want bread but we want roses too." Considered one of the most important events of the American labor movement, this strike is also known for being the first example of successful mobilization of immigrants and women in the history of union militancy. Although, owing to their lower numbers and their inexperience, Syrian American women never equaled the activism of their Italian peers, their efforts in favor of collective interests gave them an additional legitimacy that allowed them to participate more in the public arena. ${ }^{22}$

In a general way, the range of demands made by Arab women was still very large and concerned the class divisions and relations between newcomers and those long since established in the United States. How did Arab women address the question of gender relations? Here again, the social context in the United States played a decisive role.

\section{The premises of a feminist discourse}

When the earliest female immigrants settled in the United States around 1860, the condition of women was a major subject of debate. For over a decade already, following the famous Seneca Falls convention of 1848, American feminists, whose figureheads were Elizabeth Cady Stanton and Lucretia Mott, had been organizing new annual conventions the main goal of which was obtaining the right to vote. Though, at this period, gender equality was still far from being established, a certain number of advances are perceptible, notably as

21 Watson 2005: 111.

22 Syrian Americans' political awareness was less sharp than that of immigrants from the Italian peninsula where Marxist or anarchist ideologues had been organizing a big part of the working class since beginning of the twentieth century. As early as 1902, socialist activists led by Giacinto Menotti Serrati founded the first Italian socialist federation (Federazione Socialista Italiana) in New York. On the political commitment of Italian women workers, see Bencivenni, 2011. 
regards education. New schools reserved exclusively for women were created, such as Wellesley College in 1870 or Radcliffe in 1874, and allowed American women access to occupations that had formerly been forbidden to them. But there was one domain in which women had recognized experience and enjoyed a space of unprecedented freedom. This was community groups and philanthropic works. In the early nineteenth century, following the second Great Awakening, ${ }^{23}$ the women of the American bourgeoisie initiated a reform movement and tackled a certain number of political and social questions. Slavery, of course, alcoholism and poverty, were so many battles thanks to which American women entered the public space and progressed toward greater emancipation. ${ }^{24}$

Following the model given by the dominant culture, Arab women who had recently integrated into the middle classes or who had issued from the "Syrian" social elite, also undertook to create their own charitable organizations. Founded in 1896, the Syrian Women's Union in Boston organized events whose profits were donated to the poorest Arab families. Similarly, in 1917, the Syrian Ladies' Aid Society of New York was also founded with the goal of financially, medically and morally assisting those who arrived in the port city. At the same time, certain Anglo-American associations provided assistance to newly arrived immigrants. Denison House, a famous settlement house ${ }^{25}$ created in Boston in 1892, financially supported several Syrian clubs by organizing charitable works. Within these associations, bonds were built up between Anglo-Americans, Syrian Americans and immigrants, each group learning to discover one another. The ambitions of the heads of certain of these associations went well beyond the immediate needs of immigrant populations. The founders of Denison House, Emily Greene Balch and Helena Dudley, who were very involved in the mobilization of American women to demand the right to vote, gave their Arab protégées many opportunities to join

\footnotetext{
${ }^{23}$ A movement of spiritual revival that began in 1830 in the Midwest and the south of the United States.

${ }^{24}$ On American women's involvement in community groups, see Women in Antebellum Reform by Lori B. Ginsberg (Ginsberg: 2000).

25 A sort of social center which also promoted the Americanization of immigrants.
} 
the suffrage movement. Between 1909 and 1913, the city of Boston was the scene of harshly repressed feminist demonstrations, during which Syrian women activists marched next to their Anglo-American counterparts. This is what was reported in the archives of Denison House:

Today in the streets of Boston, women from Lebanon, Tripoli,

Damascus and Albania marched proudly through the city, alongside American women. ${ }^{26}$

The American charitable tradition and the philanthropic movement therefore offered Arab women the possibility of appropriating new codes of behavior and of getting involved in social questions. In the early twentieth century, the wives and daughters of the Arab middle classes were active in most sectors of public life: aid to the poor, education and culture were some of the areas in which they gained greater margins of autonomy. But above all, in contact with American feminists, they took hold of issues of sexual discrimination and civil rights. But how was the step between American feminism and Syrian American feminism taken? How did an Arabic feminist discourse get articulated on American soil?

As we have seen, American missionaries had a significant influence on their students, many of whom subsequently immigrated to the United States in order to pursue an education. The crystallization of feminist aspirations and the definition of a "gender and ethnicity" paradigm was the work of these intellectuals, particularly by means of the press and what was called Mahjar literature - the literature of the diaspora.

\section{The feminism of the Mahjar}

The United States between 1901 and 1910 accepted a record number of eight million immigrants. Unlike their predecessors, the "new immigrants" were mostly from Southern Europe, the Balkans and the

${ }^{26}$ Quoted in Shakir 1997: 60. 
Eastern Mediterranean region. ${ }^{27}$ The population of the large American metropolises was thus composed of a multitude of foreign communities that equipped themselves with cultural structures, one of the cornerstones of which was the ethnic press. The Syrian Americans, though comparatively less numerous than the Italians or the Slavs, turned out to be particularly productive in this area. In 1892, the Maronites of New York City founded the first Syrian newspaper, called Kawkab America ("The Star of America"). In 1899, the Greek Orthodox community in turn created their own daily newspaper. By 1910, there were more than fifteen Arabic journals in the United States.

The main function of this ethnic press was to keep readers informed of events happening in their home countries. At the same time, however, these papers sought to help new immigrants with the integration process. As a general rule, the spirit of this press was rather conservative and its tone largely sectarian. Having for the most part succeeded in their integration into American culture, the Syrian Americans were more concentrated on making the most of their new lives than in defending their cultural heritage. More significantly, the massive influx of these new immigrants provoked increasing xenophobia in public opinion. Though few in number, Syrian Americans were nevertheless subject to racist attacks and sometimes referred to as "Mediterranean trash." 28 They were also accused of being political agitators; this was the view of the historian Herman Feldman in 1908:

Employers regard Syrians unfavorably because they're a lot of trouble makers, much too fond of radical labor movements. ${ }^{29}$

This was clearly not a favorable time for any exhibition of ethnic pride. Such is the conclusion of Sharon McIrvin Abu-Laban in her comparative study of different migratory groups: "In the community,

${ }^{27}$ The expression "new immigrants" is used for example by Degler et al. 1980: 435. It is used to bring out the contribution, between 1900 and 1920, of new source countries.

28 Younis 1995: 218.

${ }^{29}$ Quoted in Younis 1995: 219. 
there was an emphasis on low-profile acculturation and adaptation to the dominant patterns." 30

Yet, around the turn of the twentieth century, there was a resurgence of fervent nationalism in the original homeland of these immigrants. Related to the Arab Renaissance (Nabda) that had developed in the Syrian provinces of the Ottoman Empire a few years earlier, this movement advocated the unity of all Arabicspeaking "Syrians" and defended an ecumenical conception of group identity. A new milestone was reached in 1905 with the publication of Nagiv Azoury's book The Awakening of the Arab Nation, in which Azoury, a Syrian Lebanese Maronite, denounced the mechanisms of Turkish oppression which used cultural and religious specificities to weaken the unity of the Arabic-speaking people. Feminist activists in the Middle East seized this opportunity to bring to light the multiplicity of forms of Turkish oppression. ${ }^{31}$ They claimed that their cause had to be heard; in their eyes, the status of women and the nationalist platform were intimately connected. Throughout the Middle East, new publications addressed to women began to appear, such as al-A'rus in Damascus in 1910 and al-Kitadir in Beirut in 1912. Simultaneously, articles and books were written by men for whom national renaissance was inseparable from the emancipation of women. The Egyptian writer Amin Qasim remains the most well known of these reformers. In his pioneering 1899 work called The Liberation of Women, Qasim pleaded for the education of women, for the reform of divorce laws and for the abandonment of the Islamic veil. More importantly, Qasim developed the idea that the subjection of the Arab people and the cultural paralysis that resulted from it could not be fought without a balancing of gender relations:

When the status of a nation is low, reflecting an uncivilized condition for that nation, the status of women is also low, and when the status of the nation is elevated, reflecting on the progress and civilization of that nation, the status of the women in that country is also elevated. ${ }^{32}$

\footnotetext{
${ }^{30}$ McIrvin Abu-Laban 1989: 51.

31 See for example the writings of the "Syrian" journalist Hind Nawfal, who founded in 1892 the Egyptian newspaper al-Fatat ("Young Woman").

32 Quoted in Mazid 2002: 59.
} 
Syrian American intellectuals were inspired by these elites in the Middle East, and began to define and defend a secular Arab identity in the United States. Their ambition was to bring together the various Arabic-speaking religious communities and to protect their common cultural heritage. At this time, the ethnic press opened its columns to nationalist militants as well as to feminist intellectuals. This last group attempted to make the voices of women in the diaspora community heard, and to take advantage of the focus on identity to reform the hierarchy of social roles. The novelist and journalist Afifa Karam was, in this context, a pioneering figure. After marrying at the age of fourteen, she immigrated with her husband to the United States in 1897 and was hired as a reporter by the weekly Arabic newspaper $A l$ Hoda. In 1913, she founded a magazine of her own titled al-'Alam aljadid an-nisa'iya (The New World for Women) whose ambition was to offer a critical perspective on the status of Arab women in general:

My main intention here is to show the status of most Oriental women and the way they are treated. Oriental women are the most unfortunate creatures. They are the least knowledgeable and the last to be informed of their God-given rights which men have wrongfully usurped. ${ }^{33}$

Beside portraits of famous women, one finds articles on the necessity of educating girls. Afifa Karam asks her readers:

Is education vile or virtuous? The answer, no doubt, is virtuous. So what sin have women committed to be deprived of it? And for what reason? And according to what law? ${ }^{34}$

Similarly, Karam rebelled against the tradition of arranged marriage which she did not consider a family affair, but an infringement of women's rights. She then set out upon a vigorous critique of traditions directed at both the Syrian American community and her compatriots in Syria and Egypt. Whatever their social condition and their origin, and whether they are urban or rural dwellers, Karam writes:

\footnotetext{
${ }^{33}$ Quoted in Khater 2001: 159.

${ }^{34}$ Quoted in Shakir 1997: 56.
} 
Arab women are victims of the traditional misogyny of Eastern Mediterranean peoples where the rights and social role of women are generally denied or minimized. ${ }^{35}$

Consequently, Afifa Karam's reputation quickly reached the Middle East, where her views met with an immediate echo from her women readers. In the Egyptian newspaper for women al-Mara al Jadida, she wrote a column called "Hadith al-Mahjar" (Words from immigrants) that she inaugurated in the following terms: "Would you permit me oh, the daughter of my less developed country - to tell you something about your emigrant compatriot?"36 Though her commentaries sometimes seem condescending, her purpose was to establish a dialogue between the women who had immigrated to America and those who had remained in the East. In fact, she sought to present herself as an example of successful emancipation, since emigration from her homeland and integration into the United States had liberated her from "husbandly commands." 37 Far from the traditional social constraints, Karam encouraged her female compatriots in the East to take inspiration from the progress made by Syrian American women.

Take another example, that of Hanna Kasbani Kourani. A teacher at the American School for Girls in Tripoli before turning toward journalism, Kourani settled in Chicago in 1893. In that year, she participated in the International Women's Meeting organized by American feminists. She gave a rather conservative speech that accepted the cult of domesticity of certain women of the bourgeois class: "The domestic plan is natural for women and they must not overstep it." 38 However, after several years during which she gave lectures, participated in conventions, and noted the emancipation of earlier immigrants, Kourani eventually cast away the inherited dogmas and radicalized her positions. In 1901, a short time before her premature death at 29 years old, Kourani made a trip to Beirut where she bore witness to her experience in America. She gave a speech that, on the

\footnotetext{
${ }^{35}$ Quoted in Shakir 1997: 105.

${ }^{36}$ Quoted in Khater 2001: 157.

${ }^{37}$ Quoted in Shakir 1997: 30.

${ }^{38}$ Quoted in Khater 2001: 165.
} 
one hand, illustrated the experience she had had, and on the other, attested to the influence of Syrian American feminists: "Our knowledge of the greatness that women in the West have accomplished and are accomplishing should exhort us to follow suit here in the East." 39

As was the case in Arab countries, this struggle for the liberation of women was, in the United States, led by men who took advantage of the diasporic condition to undertake a more comprehensive critique of society in the Middle East. The Lebanese-born writer and poet Khalil Gibran published in 1908 a work entitled Rebellious Spirits, in which he denounced the injustices suffered by women. Composed of four tragic love stories, the book confronts head-on the problem of the condition of Arab women and their position in Lebanese society. In the first story, "Wardé El-Hani ( Freedom to Love, translated as "Madame Rose Hanie"), Gibran depicts a young girl who, having been married against her will, has fled the family home to live with the man she loves. Through this portrait, the Syrian American writer makes heard the voice of Lebanese women who suffer under the yoke of tradition: "I have been a faithful woman since I stopped selling my body for shelter and my days for clothes." 40 Gibran goes further to claim that the subordination of women is contrary to divine laws: "I have freed my love from the enslavement of corrupt human laws, so that I may live as God wants." 41 The penalty for this audacity came swiftly: in Lebanon, the book was severely criticized by the Maronite Church which judged it an unacceptable attack against the clergy and an incitement to the moral degradation of women. The work was condemned as heretical, and Gibran was excommunicated by the Maronite Patriarch.

The formulation of a feminist Arab American discourse was the work of the elite immigrant intellectuals, since their diasporic condition allowed them to reevaluate traditional institutions and practices critically, without fear of censorship. Faced with pressure to assimilate to American culture, women's emancipation was closely

\footnotetext{
${ }^{39}$ Quoted in Khater 2001: 167.

${ }^{40}$ Gibran 1980: 18.

${ }^{41}$ Gibran 1980: 23.
} 
associated, in the United States, with the defense of a new collective identity.

The confrontation with the different socio-cultural patterns of the United States inevitably provoked a questioning of the traditions of the societies that Syrian Americans had left behind.

Whether simple street peddlers or industrial workers, whether single or married, Arab women of the lower and middle classes gained greater financial independence and the possibility of being politically active. The prestige of this social mobility had the effect of reconfiguring their role in society. As they participated in the reform movements then taking place in the United States, their integration into the American middle class allowed them to redefine their roles and responsibilities within their own community as well. Finally, it has been demonstrated that, in the course of the twentieth century, ideological conflicts in the Middle East were echoed by members of the diaspora who were questioning their identity. In particular, the "Syrian" nationalist movement in the Middle East gave new life to Syrian American feminism, allowing woman of the intellectual elite to articulate a collective discourse that contributed to the defense of a cultural identity and thus to the visibility of the diaspora.

Supported and inspired by the women of Syria or of Egypt, Syrian American activists fed their nationalist aspirations with new ideas about the condition and role of women in the United States. One can thus observe how the emancipatory logic present at the turn of the twentieth century was enriched by the contributions of women activists who shared the same cultural heritage but worked in a transnational space. Far from the clichés that see Arab women as belly dancers or veiled and silent statues, the women of the Arab community were, during the period preceding the First World War, at the forefront of social, political and cultural mediation. Although their positions were diverse and changing, these women nonetheless tended to demonstrate how diaspora can inspire a reconfiguration of the symbolic features of collective identity and a reworking of gender relations. 


\section{Bibliography}

Bencivenni Marcella, 2011, Italian Immigrant Radical Culture: The Idealism of the Sovversivi in the United States, 1890-1940, New York, New York University Press.

Cadinot Dominique, 2006, Les Arabo-Américains. Processus de construction identitaire, Paris, Le Manuscrit, coll. «Le Manuscrit Université ».

Clinton Catherine, 1999, The Other Civil War: American Women in the Nineteenth Century, New York, Hill and Wang.

Degler Carl N. et al., 1980, Histoire des États-Unis. La Pratique de la démocratie, Paris, Economica [Translated from: The Democratic Experience: A Short American History, Glenview, Ill., Scott, Foresman, 1973].

GABACCIA Donna, 1995, From the Other Side: Women, Gender, and Immigrant Life in the US, 1820-1990, Bloomington, Indiana University Press.

GIBRAN Khalil, 1980, L'Esprit rebelle, Dangles, Saint-Jean-de Braye [Translated from: Al-Arwah al-mutamarridah, New York, Al-Mohajer, 1908 ; Spirits Rebellious, transl. H. M. Nahmad, New York, Knopf, 1948].

GinzBerg Lori D., 2000, Women in Antebellum Reform, Wheeling (Ill.), Harlan Davidson.

Gualtieri Sarah, 2004, «Gendering the Chain Migration Thesis: Women and Syrian Transatlantic Migration, 1878-1924», Comparative Studies of South Asia, Africa and the Middle East, 24/1, p. 69-81.

Hiтti Philip K., 1924, The Syrians in America, New York, George H. Doran.

KHATER Akram F., 2001, Inventing Home: Emigration, Gender, and the Middle Class in Lebanon, 1870-1920, Berkeley, University of California Press.

LAtrache Rim, 2006, «Les Arabo-Américains et l'affaire de Munich en 1972. La discrimination au nom de la sécurité nationale était-elle légitime ? ", Hommes \& Migrations, 1261, p. 145-155.

MAZID Nergis, 2002, "Western Mimicry or Cultural Hybridity: Deconstructing Qasim Amin's "Colonized Voice” ", The American Journal of Islamic Social Sciences, 19, p. 42-66.

MCIRvin ABU-Laban Sharon, 1989, "The Coexistence of Cohorts: Identity and Adaptation among Arab-American Muslims ", in Baha ABU-LABAN \& Michael W. Suleiman (eds), Arab-Americans: Continuity \& Change, Belmont (Mass.), Association of Arab-American University Graduates (AAUG), p. 45-64.

NAfF Alixa, 1981, "Arabs ", in Stephan Therstorm (ed.), Harvard Encyclopedia of American Ethnic Groups, Cambridge (Mass.), Harvard University Press, p. 12-136. 
—, 2002, "New York: The Mother Colony », in Kathleen Benson \& Philip M. KaYAl (eds), A Community of Many Worlds: Arab Americans in New York City, New York (NY), Museum of the City of New York/Syracuse University Press, p. 3-11.

PARRS Alexandra, 2005, Construction de l'identité arabe-américaine : entre invisibilité et mise en scène stratégique, Paris, L'Harmattan.

SHAKIR Evelyn, 1997, Bint Arab: Arab and Arab American Women in the United States, Westport (CT), Praeger.

TARAud Christelle, 2011, "Les femmes, le genre et les sexualités dans le Maghreb colonial (1830-1962)», in Pascale Barthélémy, Luc CAPDEvila \& Michelle Zancarini-Fournel (dir.), "Colonisations », Clio. Histoire, Femmes et Sociétés, 33, Toulouse, Presses universitaires du Mirail, p. 157-191.

Watson Bruce, 2005, Bread and Roses: Mills, Migrants, and the Struggle for the American Dream, New York, Viking.

Younis Adele L., 1995, The Coming of the Arabic-Speaking People to the United States, New York, Center for Migration Studies. 